\title{
TINJAUAN KRIMINOLOGIS TERHADAP KENAKALAN REMAJA DI SURAKARTA
}

\author{
Yulia Budiwati ${ }^{1}$, Dika Yudanto ${ }^{2}$ \\ ${ }^{1}$ Universitas Terbuka \\ ${ }^{2}$ Universitas Islam Batik Surakarta \\ Email :yulia@ecampus.ut.ac.id
}

\begin{abstract}
Abstrak : Penelitian tentang kriminologi terhadap Kenakalan Remaja ini dilakukan karena merupakan sebuah perilaku yang menyimpang yang terjadi pada kalangan remaja. Kenakalan remaja menunjuk perilaku remaja yang tidak sesuai dengan norma-norma yang hidup di dalam masyarakatnya. Dari segi hukum kenakalan remaja digolongkan dalam dua kelompok yang berkaitan dengan norma-norma hukum yaitu: (1) kenakalan yang bersifat amoral dan sosial serta tidak diatur dalam undang-undang sehingga tidak dapat atau sulit digolongkan sebagai pelanggaran hukum; (2) kenakalan yang bersifat melanggar hukum dengan penyelesaian sesuai dengan undang-undang dan hukum yang berlaku sama dengan perbuatan melanggar hukum bila dilakukan orang dewasa. Selanjutnya budaya atau kebudayaan berasal dari bahasa Sansekerta yaitu buddhayah, yang merupakan bentuk jamak dari buddhi (budi atau akal) diartikan sebagai hal-hal yang berkaitan dengan budi dan akal manusia. Hasil penelitian menunjukan bahwa, aparat penegak hukum benar-benar dapat memahami faktor-faktor penyebab hal tersebut, sehingga dapat merumuskan langkahlangkah yang efektif untuk mencegah agar kasus-kasus kejahatan yang dilakukan remaja tidak bertambah. Berdasarkan dari kasus yang ada di polresta Surakarta pada tahun ini terutama pada peran keluarga dalam mendidik anak pada usia remaja, tingkat kejahatan yang dilakukan oleh remaja masih tergolong rendah, hal ini dikarena peran pemerintah melalui dinas terkait dalam melakukan preventif pembinaan dan penyuluh berjalan dengan lancar dan terjadwal. Polresta Surakarta dalam menanggulangi remaja adalah: (1) Upaya preventif, berupa: (a) Penjagaan di tempat-tempat yang rawan terjadinya tindakan kenakalan remaja, (b) Patroli ke tempat-tempat yang rawan terjadinya kenakalan remaja, (c) Penyuluhan ke sekolahsekolah, masyarakat, dan karangtaruna, (d) Penyampaian pesan-pesan Kamtibmas (keamanan dan ketertiban masyarakat) kepada para warga, (e) Pengaturan lalu lintas, (f) Latihan Safety Riding. (2) Upaya Represif, berupa: (a) Upaya (b) Penggiringan ke Dinas Sosial bagi para pekerja seks komersial untuk dibina, (c) Penilangan bagi pelanggar lalu lintas, (d) Upaya rehabilitasi bagi para penyalahguna narkoba, (e) Penangkapan para pelaku kenakalan remaja untuk selanjutnya diproses secara hukum
\end{abstract}

Kata kunci : Kriminologi, Kenakalan Remaja, Surakarta

\section{LATAR BELAKANG}

Masyarakat yang sejahtera merupakan masyarakat yang kebutuhankebutuhan hidupnya dapat terpenuhi dengan memadai. Salah satu kebutuhan yang sering kali menjadi tolak ukur utama dalam mengklasifikasikan tercapai atau tidak tercapainya kesejahteraan tersebut adalah kebutuhan ekonomi. Namun sesungguhnya dalam suatau sistem kehidupan masyarakat, terdapat pula faktor lain yang juga sangat dibutuhkan, yaitu terciptanya keamanan dan ketertiban masyarakat. 
Lingkungan yang aman dan tertib akan menjamin keberlangsungan hidup masyarakat dapat berjalan dengan baik, sehingga dalam beraktifitas sehari-hari, masyarakat dapat merasa tenang tanpa merasa tercaman adanya tindakan-tindakan kriminal yang dapat merugikan mereka

Masa remaja merupakan suatu masa dimana individu berkembang dari segi kematangan seksual, kematangan psikologis serta pola identifikasi dari anak-anak menjadi dewasa dan terjadi peralihan dari yang bergantung penuh pada sosial-ekonomi ke keadaan yang lebih mandiri, untuk memenuhi tugas perkembangan remaja tentu saja memiliki tuntutan kebutuhan yang harus dipenuhi baik dari perubahan fisik, psikis dan lingkungan Willis (2014). Tuntutan-tuntutan inilah kemudian dapat menyebabkan timbulnya masalah-masalah yang akan dihadapi oleh remaja. Masalah yang akan timbul kemungkinan ada yang bisa ditangani sendiri oleh remaja akan tetapi ada juga masalah yang tidak bisa ditangani oleh remaja sehingga sangat membutuhkan orang lain guna memberikan arahan dan bimbingan didalam memecahkan masalah tersebut Willis (2014). Apabila masalah yang dihadapi oleh remaja tidak dapat teratasi, maka akan mengakibatkan remaja tersebut mengalami pengambilan keputusan yang tidak tepat, sehingga akibat yang ditimbulkan remaja dapat melakukan tindak yang tidak tepat atau perilaku menyimpang seperti pencurian, penipuan, perampokan, perkelahian, penganiayaan, pembunuhan, pelanggaran asusila, dan penggunaan narkotika yang sering disebut dengan kenakalan remaja (Willis, 2014).

Jensen dalam Sarwono 2013 mengkatagorikan kenakalan remaja menjadi 4 komponen yaitu: (1) Kenakalan yang menimbulkan korban fisik pada orang lain seperti perkelahian, pemerkosaan, pembunuhan dan lain-lain. (2) Kenakalan yang menimbulkan kerugian materi seperti perusakan, pencurian, pemerasan dan lain-lain. (3) Kenakalan sosial yang tidak menimbulkan korban di pihak orang lain seperti pelacuran, penyalahgunaan obat. (4) Kenakalan yang melawan status seperti mengingkari status orang tua dengan cara pergi dari rumah.

Dari catatan kriminal yang sudah terjadi di Indonesia didapatkan data dari kepolisian daerah yang tercatat, angka kriminalitas tertinggi dilaporkan pada tahun 2013 terdapat pada wilayah kepolisian daerah Metro Jaya dengan 49.498 kasus dan terendah terdapat pada wilayah kepolisian daerah Maluku Utara dengan 1.177 kasus. Sementara itu Jawa Tengah menempati posisi ke 7 dengan terdapat 14.859 kasus yang sudah terjadi, dari catatan kriminal yang ada pelaku kriminalitas ini bukan hanya orang dewasa tetapi remaja dan bahkan anak-anak pun ada yang pernah tercatat melalukan kriminalitas yang terlaporkan ke pihak kepolisian (Badan Pusat Statistik, 2014). Surakarta merupakan salah satu kota yang terdapat di Jawa Tengah yang Angka kenakalan remajanya cukup tinggi, tercatat di satuan resesrse kriminal Polisi Resor Kota Surakarta sepanjang tahun 2015 terjadi beberapa kasus yaitu: (1) Penganiayaan, 11 kasus. (2) Tindakan kekerasan, 3 kasus. (3) Pelecehan seksual, 5 kasus. (4) Penghinaan, 1 kasus. (5) Penggelapan, 3 kasus. (6) Pencurian, 32 kasus. (7) Pengancaman, 1 kasus. (8) Penipuan, 20 kasus. (9) Menjual miras tanpa ijin, tidak lebih dari seratus. (10) Mabuk ditempat umum seratus lebih. (11) Mengemis, kurang dari seratus. (12) Menjajakan diri, tidak lebih dari seratus. (13) Melanggar aturan lalu lintas, 7.725 kasus. Penyalahgunaan Narkoba, 12 kasus. (15) Membolos sekolah saat jam pembelajaran, seratus kasus lebih (Widayanto, 2016).

Kenakalan remaja banyak menimbulkan keresahan dalam masyarakat. Kejahatan seksual misalnya, banyak dilakukan oleh anak-anak usia remaja sampai dengan umur menjelang dewasa, dan kemudian pada usia pertengahan. Tindak merampok, menyamun dan membegal, $70 \%$ dilakukan oleh anak-anak muda berusia 17-30 tahun. Mayoritas anak-anak muda yang terpidana atau dihukum karena kejahatannya disebabkan oleh nafsu serakah untuk memiliki, sehingga mereka banyak melakukan perbuatan mencopet, menjambret, menipu, merampok, menggarong dan lain-lain. Menurut catatan kepolisian, pada umumnya jumlah anak laki-laki yang melakukan kejahatan dalam suatu lingkup gang-gang diperkirakan lima puluh kali lipat dari anak perempuan, sebab anak perempuan lebih banyak jatuh pada limbah pelacuran, promiskuitas (bergaul bebas dan 
seks bebas dengan banyak pria) dan menderita gangguan mental, serta perbuatan minggat dari rumah dan keluarganya

\section{METODOLOGI PENELITIAN}

Penelitian ini berlokasi di Kota Surakarta. Untuk memperoleh data-data yang diperlukan, secara khusus penelitian ini dilaksanakan di Polres Surakarta dan di instansi lainnya yang berkaitan dengan penelitian ini. Sumber data yang digunakan dalam penelitian ini adalah Data primer adalah data yang diperoleh atau dikumpulkan oleh peneliti secara langsung dari sumber datanya. Data Sekunder adalah data yang diperoleh atau dikumpulkan peneliti dari berbagai sumber yang telah ada dan instansi terkait.

Teknik pengumpulan data dalam proses penelitian ini dilakukan dengan dua cara yaitu Untuk mengumpulkan data primer dilakukan dengan studi lapangan (Field Research) di polres Surakarta dan data sekunder dilakukan dengan melakukan studi kepustakaan (Library Research). Data yang diperoleh dalam penelitian ini, selanjutnya dihubungkan dengan teori dan dianalisis secara kualitatif, kemudian dideskripsikan dengan menguraikan dan menggambarkan permasalahanpermasalahan yang dimaksud dalam penelitian ini

\section{Bagan Penahapan Pelaksanaan Penelitian}

\begin{tabular}{|l|l|l|l|}
\hline \multicolumn{1}{|c|}{ Proses } & \multicolumn{1}{|c|}{ Luaran } & \multicolumn{1}{c|}{ Indikator Capaian } & \multicolumn{1}{c|}{ Pelaksana } \\
\hline Studi Literatur & $\begin{array}{l}\text { 1. Proposal } \\
\text { 2. Materi kuesioner } \\
\text { 3. Pedoman wawancara } \\
\text { 4. Pedoman Pengamatan }\end{array}$ & $\begin{array}{l}\text { Tersusun proposal, } \\
\text { kuesioner, pedoman } \\
\text { wawancara, \& pedoman } \\
\text { pengamatan }\end{array}$ & $\begin{array}{l}\text { Ketua dan } \\
\text { anggota }\end{array}$ \\
\hline $\begin{array}{l}\text { Menyebarkan } \\
\text { kuesioner pada } \\
\text { informan } \\
\text { sasaran }\end{array}$ & Kuesioner terisi & $\begin{array}{l}\text { Kuesioner terisi } \\
\text { sejumlah sampel yang } \\
\text { telah ditetapkan }\end{array}$ & $\begin{array}{l}\text { Petugas } \\
\text { lapangan }\end{array}$ \\
\hline $\begin{array}{l}\text { Melakukan } \\
\text { wawancara } \\
\text { mendalam } \\
\text { dengan } \\
\text { informan }\end{array}$ & Deskrpsi hasil wawancara & $\begin{array}{l}\text { Hasil wawancara } \\
\text { mendukung data survey }\end{array}$ & $\begin{array}{l}\text { Ketua, anggota, } \\
\text { dan petugas } \\
\text { lapangan }\end{array}$ \\
\hline $\begin{array}{l}\text { Melakukan } \\
\text { pengamatan } \\
\text { terbatas }\end{array}$ & $\begin{array}{l}\text { Deskripsi hasil } \\
\text { pengamatan }\end{array}$ & $\begin{array}{l}\text { Hasil wawancara } \\
\text { mendukung data survey }\end{array}$ & $\begin{array}{l}\text { Ketua, anggota, } \\
\text { dan petugas } \\
\text { lapangan }\end{array}$ \\
\hline $\begin{array}{l}\text { Melakukan } \\
\text { interpretasi dan } \\
\text { analisis data }\end{array}$ & Draf laporan penelitian & Draf laporan tersusun & $\begin{array}{l}\text { Ketua dan } \\
\text { anggota }\end{array}$ \\
\hline $\begin{array}{l}\text { Membuat } \\
\text { laporan }\end{array}$ & Laporan penelitian & Laporan penelitian final & $\begin{array}{l}\text { Petugas } \\
\text { lapangan }\end{array}$ \\
\hline
\end{tabular}

\section{HASIL DAN PEMBAHASAN}

Faktor-faktor yang menyebabkan kenakalan remaja di Surakarta. 
Berdasarkan hasil penelitian yang dilakukan di Polresta Surakarta terhadap kasus-kasus kenakalan yang terjadi diantaranya bahwa faktor faktor yang menyebabkan kenakalan remaja disurakarta yang terjadi adalah :

1) Keluarga Sebagai Penyebab Kenakalan Remaja dan Peranan Kontrol di Dalamnya

Keluarga merupakan lingkungan yang terdekat untuk membesarkan, mendewasakan dan didalamnya anak mendapatkan pendidikan yang pertama kal. paling kuat dalam membesarkan anak terutama bagi anak yang belum sekolah. Oleh karena itu keluarga memiliki peranan yang penting dalam perkembangan anak, keluarga yang baik akan berpengaruh positif bagi perkembangan anak, sedangkan keluarga yang jelek akan berpengaruh negative. Adapun keadaan keluarga yang dapat menjadi sebab timbulnya delinquency dapat keluarga yang tidak normal (broken home), keadaan keluarga yang kurang menguntungkan

2) Broken Home dan Quasi Broken Home Menurut pendapat umum pada broken home ada kemungkinan besar bagi terjadinya kenakalan remaja, dimana terutama perceraian atau perpisahan orang tua mempengaruhi perkembangan si anak.

3) Keadaan Jumlah Anak yang Kurang Menguntungkan Aspek lain didalam keluarga yang dapat menimbulkan anak remaja menjadi delinquency adalah jumlah anggota keluarga (anak) serta kedudukannya yang dapat mempengaruhi perkembangan jiwa anak. (Sudarsono 2012). Peran orang tua dalam menentukan sikap, perilaku anak dan faktor-faktor apa saja yang menyebabkan kenakalan di Laweyan Kota Surakarta maka peneliti mewawancarai 5 kepala keluarga dengan 16 pertayaan. Penelitian yang dilakukan terhadap orang tua di Kecamatan Laweyan, dengan mengajukan pertanyaan pertanyaan melalui wawancara mengenai peran orang tua dalam mendidik anak remaja

Adapun Peran orang tua dalam mendidik anak adalah pola mendidik bertipe militer, pola mendidik bertipe permisif, pola mendidik bertipe komunikatif/demokrasi. Adapaun penjabaranya sebagai berikut ini:

Pola Mendidik Bertipe Mititer Pola mendidik yang dilakukan oleh orang tua sangat beragam. Kecendrungan mempraktekkan cara mendidik tertentu biasanya dipengaruhi oleh latar belakang orang tua. Orang tua yang pada masa kecilnya mendapat pendidikan yang keras dan tegas akan memiliki kecendrungannya kepada anaknya. Pada perkembangannya orang tua akan memaksakannya kedisiplinan kepada anak-anaknya, meskipun untuk melakukan hal tersebut orang tua harus bersikap tegas, keras dan tidak sedikit menggunakan ancaman, hukuman atau kekerasan kepada anak-anaknya. Orang tua seperti ini beranggapan apa yang dilakukannya sematamata mengedepankan kuatnya keinginan dan cita-cita agar anak meraih keberhasilan dimasa datang. Mereka selalu berpikiran apa yang mereka lakukan demi kebaikan anak, meskipun harus mengesampingkan perasaan dan kondisi anak. Seolah dalam camp militer, anak dipaksa mengikuti peraturan yang sudah ditetapkan oleh orang tua dan hukuman telah menunggu bagi siapa saja yang melanggarnya. Inilah pola mendidik anak bertipe militer. Ada perintah dan aturan yang tegas, ada sanksi yang keras dan cenderung tidak ada toleransi bagi pelanggaran.

Pola Mendidik Bertipe Permisif Tipe orang tua yang bersifat seperti ini yaitu orang tua yang tega membiarkan anaknya tanpa mendidik mereka sedikitpun. Jangankan mendidik anak dalam hal pemahaman dan pelaksanaan Agama, mendidik anak untuk bersikap baik tidak pernah dilakukannya. Tipe permisif menetapkan orang tua sebagai sosok yang tidak bertanggung jawab terhadap pendidikan anaknya. Mereka memberikan kebebasan kepada anak untuk melakukan apapaun yang disukainya, sementara kontrol orang tua terhadap apa yang dilakukan anak sangat rendah atau bahkan tidak memperdulikannya. Orang tua yang seharusnya menjadi penuntun dan pengendalian anak justru menjadi penonton tanpa memberikan alasan yang jelas. tanpa memberikan alasan yang jelas. 
Pola Mendidik Bertipe Komunikatif/Demokratis Pola mendidik jeni ini mengedepankan adanya komunikasi dua arah antara orang tua dan anak. Orang tua membiasakan dirinya dan anaknya untuk saling berdiskusi, bertukar pendapat, atau saling berkomunikasi terhadap setiap permasalahan yang ada. Meskipun usia anak masih belia, tidak ada salahnya bila ia dibiasakan untuk selalu diajak berkomunikasi dua arah. Orang tua menyampaikan hal-hal yang perlu disampaikan pendapatnya berdasarkan kemampuan daya pikirnya.

\section{4) Lingkungan Sekolah yang tidak Menguntungkan}

Lingkungan sekolah adalah lingkungan dimana anak berada dalam lingkungan situasi belajar, dan lingkungan ini sangat berpengaruh terhadap tumbuh kembang kepribadian anak. Suasana lingkungan sekolah yang bagus sangat mendukung tumbuh kembang kepribadian yang bagus bagi siswa dan suasana belajar yang nyaman yang membentuk kedisiplinan belajar dan kedisiplinan sekolah. Lingkungan sekolah yang tidak menguntungkan menyebabkan pola perubahan perilaku siswa yang tidak terarah. Dukungan dari peran guru yang ada disekolah sangat berpangaruh didalam pola perkembangan siswa dalam pembentukan karakter. Lingkungan sekolah meliputi : a. Lingkungan fisik sekolah, meliputi suasana dan prasarana, prasarana dan prasarana belajar, sumber-sumber belajar dan sarana media belajar. b. Lingkungan sosial, menyangkut hubungan siswa dengan temantemannya, guru-gurunya dan staf sekolah yang lain. c. Lingkungan Akademis yaitu suasana sekolah dan pelaksanaan kegiatan belajar mengajar dan berbagai kegiatan ekstrakurikuler.

Lingkungan sekolah yang kondusif, baik lingkungan fisik, sosial maupun psikologis dapat menumbuhkan dan mengembangkan motif untuk bekerja dengan baik dan produktif. Untuk itu dapat diciptakan lingkungan fisik yang sebaik mungkin, misalkan kebersihan ruanagan, tata letak, fasilitas dan sebagainya. Demikian pula lingkungan sosial psikologis. Seperti kehidupan antar pribadi, kehidupan kelompok, kepemimpinan, pengawasan, promisi, bimibingan, kesempatan untuk maju dan kekeluargaan.

Tentang lingkungan sekolah yang berupa sarana dan prasarana ditetapkan dalam Peraturan Pemerintah Republik Indonesia Nomor. 19 Tahun 2005 tentang Standar Nasional Pendidikan BAB VII tentang Standar Sarana dan Prasarana: Pasal 42

a. Setiap satuan pendidikan wajib memiliki sarana yang meliputi prabot, peralatan pendidikan, media pendidikan, buku dan sumber belajar lainnya, bahan habis pakai serta perlengkapan lainnya yang diperlukan untuk menunjang proses pembelajaran yang teratur dan berkelanjutan.

b. Setiap satuan pendidikan wajib memiliki prasarana yang meliputi lahan, ruang kelas, ruang pimpinan satuan pendidikan, ruang pendidik, ruang tata usaha, ruang perpustakaan, ruang laboratorium, ruang bengkel kerja, ruang unit produksi, ruang kantin, instalasi daya dan jasa, tempat berolahraga, tempat rekreasi dan ruang/tempat lain yang diperlukan untuk menunjang proses pembelajaran yang teratur dan berkelanjutan.

Lingkungan sosial yang menyakut hubungan antara siswa dengan siswa disuatu sekolah, hubungan siswa/siswi dengan guru, hubungan guru dengan guru, yang termasuk hubungan koordinasi antar guru sejenis dan antar guru lain yang tidak sejenis, hubungan guru dengan tenaga kependidikan, hubungan kepala sekolah dengan guru dan lain sebagainya. Sedangkan lingkungan akademis adalah suasana yang terkait dengan kegiatan belajar di sekolah, apakah kegiatan belajar megajar di sekolah berjalan dengan disiplin dan tertib atau sebaliknya, apakah kegiatan tersebut berjalan di sekolah atau tidak berjalan di sekolah.

Pada penelitian kasus yang menyebabkan remaja menjadi melanggar aturan di Surakarta adalah disebabkan factor utama adalah dalam keluarga, yang disebabkan dari Broken Home hal ini 
yang menyebabkan mereka berani melanggar aturan karena disebabkan perhatihan dari orang tua kurang.

\section{Upaya-upaya yang ditempuh oleh kepolisian dalam penanggulangan kenakalan remaja}

Penelitian ini berlokasi di: (1) Satuan Reserse Kriminal Polisi Resor Kota Surakarta. (2) Lakalantas Surakarta. (3) Satuan Pembinaan Masyarakat Polisi Resor Kota Surakarta. (4) Satuan Reserse Narkoba Polisi Resor Kota Surakarta. Berbagai macam kasus diantaranya Penganiayaan, Tindakan kekerasan, Pelecehan seksual, Penghinaan, Penggelapan, Pencurian, Pengancaman, Penipuan, Mabuk di tempat umum, Mengemis Menjajakan diri, Melanggar aturan lalu lintas, Penyalahgunaan Narkoba, Membolos sekolah saat jam pelajaran, seratus kasus lebih. Pada tahun 2020 ini polresta Surakarta menahan 3 yang melakukan tindakan kriminal kasus lain polresta Surakarta melakukan pembinaan seperti kasus pelanggaran lalulintas, kekerasan dan lain lain. Polresta Surakarta berkoordinasi pada instansi terkait apabila terjadi pelanggaran pelanggaran yang melibatkan usia remaja.

Perilaku membolos sekolah memang belum melanggar hukum dalam arti yang sesungguhnya karena yang dilanggar adalah status-status dalam lingkungan primer (keluarga) dan sekunder (sekolah) yang memang tidak diatur oleh hukum secara terinci. Akan tetapi kalau kelak remaja ini dewasa, pelanggaran status ini dapat dilakukannya terhadap atasannya di kantor atau petugas hukum di dalam masyarakat. Karena itulah pelanggaran status ini oleh Jensen digolongkan juga sebagai kenakalan dan bukan sekedar perilaku menyimpang.

Polisi Resor Kota Surakarta melakukan upaya preventif dan represif dalam menanggulangi kenakalan remaja. Upaya preventif yang dilakukan oleh Polisi Resor Kota Surakarta adalah: (1) Penjagaan di tempat-tempat tertentu untuk mencegah terjadinya kenakalan remaja, dilakukan oleh Satuan Samapta Bhayangkara. (2) Patroli, yaitu suatu kegiatan yang dilakukan 2 orang atau lebih petugas patroli sebagai usaha mencegah bertemunya niat dan kesempatan, dengan jalan mendatangi, menjelajahi, mengamati, mengawasi, memperhatikan situasi dan kondisi yang diperkirakan akan menimbulkan segala bentuk pelanggaran ataupun tindak pidana. Tindakan preventif berupa patroli ini memiliki 6 macam metode, antara lain dengan metode jalan kaki, metode bersepeda, metode sepeda motor, metode mobil, metode perairan udara, metode menggunakan anjing dan kuda. Tindakan patroli ini dilakukan oleh Satuan Samapta Bhayangkara. (3) Penyuluhan, dilakukan di sekolah-sekolah, baik di level Sekolah Menengah Pertama maupun di level Sekolah Menengah Atas, karangtaruna, dan masyarakat, upaya ini dilakukan oleh Satuan Pembinaan Masyarakat. (4) Penyampaian pesan-pesan kamtibmas (Keamanan dan Ketertiban Masyarakat) kepada masyarakat, upaya ini dilalukan oleh Satuan Samapta Bhayangkara. (5) Pengaturan di jalan, hal ini dilakukan di area jalan raya yang sekiranya perlu untuk diatur supaya arus lalu lintas menjadi teratur dan sekaligus mencegah terjadinya pelanggaran lalu lintas. Upaya ini dilakukan oleh Satuan Lalu Lintas. (6) Peatihan Safety Riding, dilakukan pada komunitaskomunitas sepeda motor agar berkendara dengan baik dan benar. Upaya ini dilakukan oleh Satuan Lalu Lintas

Upaya represif yang dilakukan oleh Polisi Resor Kota Surakarta adalah diversi, pengawasan, pembinaan, pembuatan surat pernyataan, penggiringan ke Dinas Sosial, penilangan, dan rehabilitasi. Diversi, pengawasan, pembinaan, dilakukan oleh Unit Pelayanan Perempuan dan Anak Polisi Resor Kota Surakarta. Pembuatan surat pernyataan, penggiringan ke Dinas Sosial, dilakukan oleh Satuan Samapta Bhayangkara Polisi Resor Kota Surakarta. Penilangan dilakukan oleh Satuan Lalu Lintas Polisi Resor Kota Surakarta. Rehabilitasi dilakukan oleh Satuan Reserse Narkoba Polisi Resor Kota Surakarta. Diversi yaitu pengalihan penyelesaian perkara anak dari proses peradilan pidana ke proses di luar peradilan pidana. Diversi dilakukan dengan cara mempertemukan keluarga pelaku dengan keluarga korban. Setelah kedua keluarga saling 
berhadapan, barulah dicari upaya perdamaian. Jika diversi ini berhasil, maka pelaku kenakalan remaja tidak perlu diproses ke jalur hukum. Jika diversi gagal, maka pelaku kenakalan remaja akan diproses secara hukum. Ketentuan mengenai diversi ini diatur dalam Bab II Undang-Undang Nomor 11 Tahun 2012 tentang Sistem Peradilan Pidana Anak. Upaya ini hanya dilakukan oleh pelaku kenakalan remaja yang masih belum berumur 18 tahun dan perbuatannya tidak diancam dengan pidana penjara paling singkat 7 Tahun serta bukan merupakan tindak pidana ringan dan bukan merupakan residivis.

Upaya pengawasan oleh Unit Pelayanan Perempuan dan Anak Polisi Resor Kota Surakarta yaitu diharuskannya pelaku kenakalan remaja untuk melaksanakan ibadah sesuai dengan agamanya masing-masing di tempat peribadatan dimana pelaku kenakalan remaja tinggal, selama 3 bulan dengan pengawasan dari Balai Pemasyarakatan dan pihak kepolisian. Sebagai contoh, untuk umat Islam melakukan kegiatan Sholat 5 waktu di Masjid atau Musholla, untuk yang umat Nasrani menghadiri kebaktian pada hari minggu di gereja. Upaya pengawasan merupakan upaya lanjutan dari upaya kekeluargaan. Artinya jika upaya kekeluargaan berhasil, maka upaya pengawasan ini diberlakukan terhadap pelaku kenakalan remaja. Namun jika upaya kekeluargaan gagal, maka upaya pengawasan ini tidak diberlakukan pada pelaku kenakalan remaja, melainkan langsung diproses hukum. Upaya pengawasan ini juga diterapkan jika pelaku kenakalan remaja diputus hakim mendapatkan tindakan berupa dikembalikan ke orangtua. Upaya pengawasan ini hanya berlaku bagi pelaku kenakalan remaja yang masih belum berusia 18 tahun dan perbuatannya tidak diancam dengan pidana penjara paling singkat 7 Tahun serta bukan merupakan tindak pidana ringan dan bukan merupakan residivis.

Pembuatan surat pernyataan, yaitu upaya bagi Satuan Samapta Bhayangkara Polisi Resor Kota Surakarta untuk menanggulangi kenakalan remaja secara represif. Upaya tersebut dilakukan dengan disuruhnya pelaku kenakalan remaja akan untuk membuat surat pernyataan di depan orangtua dan guru sekolahnya yang isi surat itu menyatakan tidak akan lagi mengulangi perbuatan nakalnya itu. dan jika setelah membuat surat pernyataan pelaku kenakalan remaja kembali mengulangi perbuatannya, maka untuk perbuatan pengulangannya itu akan langsung diproses hukum. Namun jika kepolisian manganggap kenakalan yang dilakukan itu berbahaya dan seharusnya langsung diproses secara hukum, maka upaya pemanggilan orangtua dan guru tidak dilakukan, melainkan si pelaku langsung diproses hukum. Upaya pembuatan surat pernyataan ini hanya dilakukan pada pelaku tindak pidana ringan. Penggiringan ke dinas sosial, yaitu dibinanya pelaku kenakalan remaja oleh para petugas dinas sosial. Upaya penggiringan ke dinas sosial ini diberlakukan pada para pekerja seks komersial dan para pengemis pada saat tertangkap razia. Penilangan, yaitu upaya yang dilakukan pada para pengguna jalan yang melanggar aturan lalu lintas. Diharapkan penilangan ini mampu menyadarkan pelanggar untuk menaati aturan berlalu lintas dan tidak lagi mengulangi pelanggaran yang dibuatnya.

\section{Peran keluarga dalam mendidik anak pada usia remaja}

Menurut Efendy (2000), peran orangtua dalam mendidik anaknya amat menentukan pembentukan karakter dan perkembangan kepribadian anak. Saluran komunikasi yang baik antara orangtua dan anaknya dapat menciptakan suasana saling memahami terhadap berbagai jenis masalah keluarga, terutama tentang problematika remaja, sehingga kondisi ini akan berpengaruh terhadap sikap maupun perilaku yang akan dibawakan anak sesuai dengan nilai yang ditanamkan orangtua. Orang tua sangat berpengaruh terhadap pendidikan anak, sebab orang tua merupakan guru pertama dan utama bagi anak. Adapun peran orang tua menurut Kartono (1985: 85) adalah

1) Sebagai pelindung pemelihara keluarga Orang tua yang bertanggung jawab akan selalu berani berkorban memperhatikan dan mengawasi serta menyampaikan diri demi kebaikan akhlak anak-anaknya baik itu perkataan atau perbuatan. 
2) Sebagai teladan Diantara banyak tanggung jawab orang tua terhadap anak sebagai pemimpin dalam keluarga harus dapat memberikan perhatian. Disamping itu perlu adanya contoh yang baik, budi pekerti merupakan salah satu untaian mutiara pendidikan yang harus diberikan kepada anak. Adapun figure keteladanan orang tua, anak akan cenderung meniru segala yang dilihat dan diperbuat baginya. Pepatah mengatakan, "buah jatuh tidak jauh dari pohonnya".

3) Sebagai motivator Anak terdorong untuk bertindak apabila ada satu dorongan. Dalam hal ini sangat diperlukan sekali terhadap anak yang masih memerlukan motivasi. Motivasi bisa berbentuk dorongan, harapan dan penghargaan atau hadiah terhadap prestasinnya. Hal ini dilakukan agar anak ada rangsangan dalam kegiatan belajarnya.

4) Sebagai fasilitator Pendidikan akan berjalan dengan baik apabila fasilitas tersedia, namun bukan berarti orang tua memaksakan dirinya dalam memenuhi fasilitas tersebut. Setidaknya orang tua sedapat mungkin memenuhi fasilitas yang diperlukan anaknya.

5) Sebagai figur utama Orang tua adalah orang yang dianggap segalanya oleh anak-anaknya, karena bagaimanapun beliau merupakan orang yang pertama dijadikan figur. Selain itu orang tua juga harus memiliki sifat keterbukaan terhadap anak-anaknya, sehingga cepat terjalin hubungan yang harmonis antara orang tua dengan anak dan begitu juga sebaliknya. Menurut Zakiyah Drajat (1996: 35) orang tua merupakan pendidik utama dan pertama bagi anak-anak mereka, karena dari merekalah anak mula-mula menerima pendidikan. Orang tua adalah orang dewasa pertama yang memikul tanggung jawab pendidikan sebab secara alami anak pada masa-masa awal kehidupanya berada di tengah-tengah ibu dan ayahnya.

Berdasarkan dari kasus yang ada di Polresta Surakarta pada tahun ini terutama pada peran keluarga dalam mendidik anak pada usia remaja tingkat kejahatan yang dilakukan oleh remaja masih tergolong rendah, hal ini dikarena peran pemerintah melalui dinas terkait dalam melakukan preventif pembinaan dan penyuluh berjalan dengan lancar dan terjadwal.

\section{KESIMPULAN DAN SARAN}

Polresta Surakarta dalam menanggulangi kenakalan remaja adalah: (1) Upaya preventif, berupa: (a) Penjagaan di tempat-tempat yang rawan terjadinya tindakan kenakalan remaja, (b) Patroli ke tempat-tempat yang rawan terjadinya kenakalan remaja, (c) Penyuluhan ke sekolahsekolah, masyarakat, dan karangtaruna, (d) Penyampaian pesan-pesan Kamtibmas (keamanan dan ketertiban masyarakat) kepada para warga, (e) Pengaturan lalu lintas, (f) Latihan Safety Riding. (2) Upaya Represif, berupa: (a) Upaya (b) Penggiringan ke Dinas Sosial bagi para pekerja seks komersial untuk dibina, (c) Penilangan bagi pelanggar lalu lintas, (d) Upaya rehabilitasi bagi para penyalahguna narkoba, (e) Penangkapan para pelaku kenakalan remaja untuk selanjutnya diproses secara hukum.

Hambatan yang dialami kepolisian dalam menanggulangi kenakalan remaja adalah susahnya mencapai kata sepakat dalam upaya kekeluargaan, putusan hakim yang terlalu ringan, aturan hukum yang kurang memadai, ketidaktahuan mengenai hukum yang sedang berlaku, ketidaksesuaian jadwal penyuluhan dengan agenda di sekolah, kurangnya kesadaran hukum dalam berlalu-lintas, kurangnya koordinasi dengan Dispora dan masyarakat.

\section{Saran}

Bagi masyarakat, seharusnya lebih peduli lagi pada remaja, baik yang dikenali maupun yang tidak kenal. membantu polisi untuk menangani kenakalan remaja. menegur remaja yang berindikasi akan dilakukannya tindakan kenakalan.

Bisa jadi alasan kenapa dilakukannya tindakan kenakalan oleh mereka disebabkan oleh kurangnya perhatian dari orang lain. Bagi Kepolisian, khususnya Polisi Resor Kota Surakarta, seharusnya upaya penanggulangannya lebih diperbanyak lagi, baik itu preventif maupun represif. 
Penambahan penanggulangan secara preventif misalnya saja dengan menambah jam-jam patroli agar nantinya mengurangi peluang dan kesempatan dilakukannya kenakalan remaja. Penambahan penanggulangan secara represif misalnya saja dengan dimasukkannya pelaku kenakalan remaja ke pondok pesantren selama beberapa hari untuk diberikan bimbingan keagamaan. Mengadakan event-event keolahragaan yang pesertanya adalah remaja, tujuannya adalah memotifasi para remaja untuk berkompetisi secara positif. Sehingga dengan harapan jumlah kenakalan remaja akan bisa diminimalisir.

\section{DAFTAR PUSTAKA}

Alam, A.S. dan Amir Ilyas. 2010. Pengantar Kriminologi. Pustaka Refleksi: Makassar.

Ali, Achmad. 2009. Menguak Teori Hukum(Legal Theory) dan Teori Peradilan (Judicialprudence)

Termasuk Interpretasi Undang-Undang (Legisprudence). Kencana: Jakarta.

Chazawi, Adami. 2005. Tindak Pidana Mengenai Kesopanan. PT RajaGrafindo: Jakarta.

Chazawi . 2010. Kejahatan Terhadap Tubuh dan Nyawa. Cetakan ke-5. PT RajaGrafindo Persada: Jakarta.

Gunarsa, D, Singgih. dan Yulia D. Gunarsa. 2004. Psikologi Praktis Anak Remaja dan Keluarga. Cetakan ke-8. PT BPK Gunung Mulia: Jakarta.

Kartono, Kartini. 2001. Patologi sosial. Cetakan ke-7. PT RajaGrafindo Persada: Jakarta.

Marpaung, Leden. 2002. Tindak Pidana Terhadap Nyawa dan Tubuh. Cetakan ke-2. Sinar Grafika: Jakarta.

Muhammad Surya, Psikologi Pendidikan, (Dirjen Dikdasmen: Direktorat Kependidikan, 2004), h. 78

Sunarto dan B. Agung Hartono, Perkembangan Peserta Didik, (Jakarta: Rineka Cipta, 2008), h. $175-176$

Moeljatno. 2002. Asas-Asas Hukum Pidana. Cetakan ke-7. . PT Rineka Cipta: Jakarta

Moeljatno. 2009. Kitab Undang-Undang Hukum Pidana. Cetakan ke-20. PT Bumi Aksara: Jakarta. Santoso, Topo, dan Eva Achjani Zulfa. 2012. Kriminologi. Cetakan ke-12. PT Raja Grafindo Persada: Jakarta.

Rukmini, Mien. 2006. Aspek Hukum Pidana Dan Kriminologi, Cetakan Ke-1. PT Alumni: Bandung.

Santoso, Topo, dan Eva Achjani Zulfa. 2012. Kriminologi. Cetakan ke-12. PT RajaGrafindo Persada: Jakarta

Sarwono, W, Sarlito. 2012. Psikologi Remaja. Cetakan ke-15. PT RajaGrafindo Persada: Jakarta. Sasangka, Hari. 2003. Narkotika dan Psikotropika dalam Hukum Pidana. Cetakan ke-1. Mandar Maju: Bandung.

Soekanto, Soerjono, dan Sri Mamudji. 2006. Penelitian Hukum Normatif: Suatu Tinjauan Singkat. Cetakan ke-8. PT Raja Grafindo Persada: Jakarta.

Sudarsono. 2004. Kenakalan Remaja. Cetakan ke-4. PT Rineka Cipta : Jakarta.

Tongat. 2003. Hukum Pidana Materiil:Tinjauan Atas Tindak Pidana Terhadap Subyek Hukum dalam Kitab Undang-Undang Hukum Pidana. Djambatan: Jakarta

Undang-Undang Nomor 23 Tahun 2003 Tentang Perlindungan Anak. Undang-Undang Nomor 35 Tahun 2009 Tentang Narkotika

Undang-Undang Nomor 11 Tahun 2012 Tentang Sistem Peradilan Pidana Anak 